\title{
MANAGEMENT OF HUMAN RESOURCE DEVELOPMENT ON EDUCATION QUALITY EFFORTS IN PESANTREN AL-MUSLIMUN SUMBERAGUNG PLAOSAN MAGETAN Rahman Yurisya alqoulutstsaabit@gmail.com
}

\begin{abstract}
Improvements to the quality of existing human resources in schools should receive more attention than the development of facilities and infrastructure. Because as written in Law No. 14 year 2005, that HRD is the most strategic factor in national education development and most decisive for the success of an educational institution. This research was conducted to find out how the implementation of human resource development management in an effort to improve the quality of education in Pesantren Al-Muslimun Sumberagung Plaosan Magetan, knowing how the role of human resource development management in improving the quality of education in Pesantren Al-Muslimun Sumberagung Plaosan Magetan, and knowing what factors which become supporters and obstacles in the implementation of human resource development management in Pesantren Al-Muslimun Sumberagung Plaosan Magetan. This research is field research with qualitative approach. The data are generated from interviews, observations, and documentation. While the steps of data analysis in this research with the process, data collection, data reduction, display data, take conclusions and verification. From the results of the research it is known that managerial and operational, the function of human resource management has been done in Pesantren alMuslimun Sumberagung Plaosan Magetan and proved to play a very positive role. This can be seen in the process, implementation, and procedures in the stages of planning, management, employment, compensation, development and training, evaluation and dismissal. Although there are some light evaluation notes as well as a few inhibiting factors that should be solved and become the concern to be improved in the future.
\end{abstract}

Keywords: Management, Resource Development, Education Quality, Improvement Efforts

\section{A. Introduction}

Education is part of a major need in human life. When an education on a nation is able to produce qualified human beings inward and inner, of course, at the 
same time the nation can become advanced, safe, and prosperous. On the contrary, if education on a nation road in place or backward, of course the nation experiencing lags that leads to destruction in all aspects.

Especially in the development era as today, education has a central function in the development of the nation. Through education it can be printed the next generation that will play a major role in advancing the nation to a better direction.

Abuddin Nata stated that "the advancement of a nation requires the existence of superior human resources, and the existence of superior human beings requires superior education, and the existence of superior education requires the existence of various components or aspects of a superior education as well. To that superior education hope to build a superior nation will be realized." ${ }^{1}$

Therefore, preparing qualified human resources is a must in realizing valuable and quality education.

Therefore, without prejudice to the importance of other factors contributing to the quality of education, the educators and education personnel (HRD) in the school must have optimal management and development.

Because human is a central and strategic factor in all activities in an organization or institution. It is due to the form and purpose of an organization or institution, it is made based on the vision for the benefit of humans and in the implementation of its mission is organized and managed by humans as well.

Upgrading and improving the quality of existing human resources in schools should take precedence over the construction of facilities and infrastructure. Because of the existence of qualified human resources are needed to face the demands of the task and especially to answer the challenges of the future. So the development of human resources is an absolute necessity to do. ${ }^{2}$

For that we need a special management called human resource development management. That is an effort to achieve educational goals that educate students to mature and intelligent, which should be implemented effectively and efficiently. Effective is the management effort which must be able to achieve the goal while efficient that is management which must move all resources owned by educator, learner, curriculum purpose, process of learning and others.

1 Abuddin Nata, Perspektif Islam Tentang Strategi Pembelajaran (Jakarta: Kencana, 2009), 1.

2 Kadarisman, Manajeman Pengembangan Sumber Daya Manusia (Jakarta: PT Raja Grafindo, 2013), 1 . 
As stated in Chapter III, article 4, paragraph 6 that the principle of the implementation of education is to empower all components of society through participation in the implementation and quality control of education services. ${ }^{3}$

Normally every human being does not like the stagnant and monotonous situation, he/she always tries to make changes towards the better than the previous situation. Including educators in school, the existing human resources should do not feel enough with the science and stock they have, they must develop the talent and the ability to teach in order to create a good learning atmosphere and quality.

So every educational institution wants an increase in human resources that it has. All educational institutions also agree that improving human resources is an aspect that should always be considered to achieve the quality of education.

Although in fact, some indicators of educational quality indicate that various efforts have not shown satisfactory results. ${ }^{4}$

In general, it cannot be denied that the quality of our education is still very low. This is seen in the state of the various components of education that exist. Whether it is educators and educational staff who have not met qualified professionals nor facilities and infrastructure are not adequate. In spite of the provision of educational budget which is still minimal. Meanwhile from the outside of the education system, there is a globalization and information flow that has not been utilized as it should, so it also contributes to the low quality of our education.

For example, from the results of the Hong Kong-based PERC (The Political and Economic Risk Consultancy) which is located at Hongkong and is published by The Jakarta Post in September 3, 2005, it is showed that the quality of our country's education is currently very low when it is compared to other countries. ${ }^{5}$

Of course this becomes contradictory to the intent and mandate of Law No. 20 year 2003 on the National Education system, Chapter II, article 3, which explained that:

"National education function to develop the ability, forming the character and civilization of dignified nation in order to educate the life of the nation, and aims for the development of potential learners in order to become a human being who believes and

3Sistem Pendidikan Nasional no 20 tahun 2003.

4 Mulyasa, Manajemen Kepemimpinan Kepala Sekolah (Jakarta: Bumi Aksara, 2013), 158.

5 Mastuki, dkk, Manajemen Pondok Pesantren (Jakarta: Diva Pustaka, 2003), 63. 
cautious to God Almighty, noble, healthy, knowledgeable, skilled, creative, independent and become a democratic and responsible citizen." ${ }^{6}$

In other words, to obtain qualified educators and educational personnel (HRD) that required human resource management is needed. This is very important because all the resources that exist in the school, whether man, material, and money, if it is not accompanied by elements of quality are very heavy to achieve quality education.

Similarly with the head of the educational institution, especially in boarding school and madrasah environments, he/she is not only as a motivator, and event organizer (EO), but he/she also determines the direction of boarding school and madrasah policies that will determine how the objectives of educational goals in general can be realized. To achieve this, the leaders of effective educational institutions are those who meet some of the following criteria:

First, able to empower teachers to carry out the learning process well, smoothly, and productively. Second, can complete the task and work in accordance with the time set. Third, able to establish a harmonious relationship with the community so that can actively involve them in order to realize the goals of school and education. Fourth, successfully apply the leadership principle in accordance with the level of maturity of teachers and other employees in school. Fifth, work with the management team. ${ }^{7}$

Even all personnel elements in the school must have the awareness and a high willingness to participate in achieving the desired educational goals together. Because, as complete as any government provisions to develop education and however modern facilities in the form of buildings, equipment, work tools, methods of work, and community support, but if humans who are in charge of running the school program that participate less, it will be difficult to achieve the desired educational goals.

Personnel or educational personnel referred to all people who are joined to work together at a school to carry out tasks in order to achieve educational goals. Personnel or education personnel in schools included principals, vice principals, teachers, administrative staff, and public servants. In order to harmonious the activities

6 Kompri, Manajemen Pendidikan 3 (Bandung: Alfabeta, 2015), 147.

7 Mulyasa, E, Kurikulum Berbasis Kompetensi, Konsep, Karakteristik, Implementasi (Bandung: PT. Remaja Rosda Karya, 2004), 126. 
in the school then all the existing personnel must have the ability and willingness and work in synergy by carrying out their respective duties solemnly with dedication.

Human Resources is the core of development and one of the inputs (factors) that determine the success of development, as well as the output or that want to be generated from the national development process.

The main key to school planning and education development programs to run optimally is in the hands of educators and education personnel (HRD) in schools. Thus it is clear that the issue of human resource management is very important to note.

So this is the necessity why researchers want to discuss issues related to, "Human Resource Development Management In Improving Educational Quality Efforts At Al-Muslimun Boarding School Sumberagung Plaosan Magetan."

Al-Muslimun Boarding School Magetan was a teenage boarding school and it includes excels boarding school in Magetan area. This can be proved by several awards that have been achieved related to the achievement of students especially in the field of Qur'an and memorization. This is one of the advantages that distinguish between AlMuslimun boarding school and other equivalent boarding schools in Magetan area.

Of course, various achievements and other rewards cannot be separated from the human resources management that it has. So that it is expected to become a boarding school that has the quality of education in the future, the more quality schools and human resources, and gave birth to bright learners. It is because good governance of human resources is a strategic factor to improve the quality of education in any educational institution.

So, this is the necessity why researcher wants to discuss issues related to, "Management of Human Resource Development on Improving Education Quality Efforts in Al-Muslimun Boarding School Sumberagung Plaosan Magetan."

Thus, this research is important to identify the implementation of human resources development management at Al-Muslimun Boarding School Sumberagung Plaosan Magetan in order to improve the quality of education.

\section{B. Research Methods}

This research is a field research that is a research conducted in the arena or field of occurrence of symptoms. ${ }^{8}$

8 M. Iqbal Hasan, Pokok-pokok Materi Metodologi Penelitian dan Aplikasinya (Jakarta: Ghalia Indonesia, 2002), 11. 
In this research, researcher used a qualitative descriptive approach. It is a method that seeks to systematically explain the subject matter derived from various sources to be analyzed in order to obtain results as a conclusion. ${ }^{9}$

The subject of this research is Al-Muslimun Boarding School Sumberagung Plaosan Magetan, of course with the consideration that this is one of the boarding school that has tried to implement human resource development management as governance in improving the quality of education.

The presence of researcher in research is one element in qualitative research. The researcher is the planner, the data collector and eventually becomes the reporting agent of his research. ${ }^{10}$

In this case, the researcher's presence includes two stages, namely pre-research stage and research implementation stage. As a key instrument, researchers should filter, assess, summarize and decide on the necessary data.

The data collected in this research is data that fit with the focus of research that is about the management of human resources development in an effort to improve the quality of education in Al-Muslimun Boarding School Sumberagung Plaosan Magetan. ${ }^{11}$

There are two types of data collected they are primary and secondary data. Primary data is data obtained directly from the source. While secondary data is data obtained from information processed by other parties, like all forms of documents.

As for the source of the data, it can be divided into two kinds they are human and non-human. A human data source functions as a subject or key informant, while non-human data sources, in the form of relevant documents to the research focus, such as pictures, photographs, meeting notes, and writings that are in conformity with the research focus serve as research objects. ${ }^{12}$

In qualitative research, data collection techniques can be divided into two kinds, namely interactive techniques and non-interactive techniques. The interactive 9 Nana Sudjana, Penelitian dan Penilaian Pendidikan (Bandung: Sinar Baru, 2000), 64.

10 Lexi J. Moelong, Metodologi Penelitian Kualitatif (Bandung: Remaja Rosda Karya, 2006), 162.

11 Wahidmurni, Cara Mudah Menulis Proposal dan Laporan Penelitian Lapangan (Malang: UM Press, 2008), 41.

12 Sutrisno Hadi, Metodologi Research; Jilid II (Yogyakarta: Andi Offset, 1981), 136. 
technique consists of interviews and observations, while documentation studies included into non-interactive techniques.

So, in this case the researchers collect data with interview techniques, observation or inspection, and documentation studies.

In detail the steps of data analysis in this research is done by the process: data collection, data reduction, display data, take conclusions, and verification. ${ }^{13}$

In order to accounted the data, then in qualitative research it requires method of checking data validity. Among them; prolonged research, continuous data collection, triangulation, discussion with peers, sufficient references, checks by research subjects, detailed description and auditing, and member checks. ${ }^{14}$

\section{Discussion of Research Results}

\section{Implementation of Human Resource Development Management}

After research at Pesantren al-Muslimun Sumberagung Plaosan Magetan is conducted, it is known that the effort of human resource development of education in improving the quality of education that has been done is as follows:

\section{a. Planning}

At Al-Muslimun boarding school Sumberagung Plaosan Magetan, before performing the recruitment of new educators and education personnel, firstly it is held human resource planning. This human resource planning consisted of work program planning and activities program for the next year at Al-Muslimun boarding school Sumberagung Plaosan Magetan. The planning of the program was formulated through the board meeting of Al-Muslimun boarding school Sumberagung Plaosan Magetan. In the planning process of each board suggested an activity program that will be planned for the next year.

With the management planning of educators and education personnel, then in the development and compilation strategy it is implemented comprehensively, so it is expected to meet the needs of the organization in the future. Such human resource

13 Lexi J. Moelong, Metodologi Penelitian Kualitatif (Bandung: Remaja Rosda Karya, 2006), 338-345. 
planning is an early stage of the implementation of human resources development management functions. ${ }^{15}$

\section{b. Organizing}

The organizing process carried out at Al-Muslimun Boarding School of Sumberagung Plaosan Magetan is a process of arranging cooperation, which is to divide each board by giving a responsibility, but actually organizing includes not only human resources but also financial resources, every implementation of the activity would require funding.

The organizational structure at Al-Muslimun Boarding School Sumberagung Plaosan Magetan included: caregiver, principal, vice principal of curriculum, vice principal of student, vice principal of infrastructure, administrator, counseling coordinator, teacher and homeroom teacher. With the organizing that has been prepared, according to the researcher it is sufficient so that in carrying out their stewardship duties each can perform their duties well and walk in accordance with the purpose that blessed together. ${ }^{16}$

\section{c. Implementation}

That is an action to make it possible for all group members to strive to achieve goals in accordance with managerial and business planning. Implementation is the process of moving people to perform activities to achieve goals so that the process of efficiency and effectiveness of the work can be achieved.

In the implementation of the Work Program at Al-Muslimun Boarding School Sumberagung Plaosan Magetan, the person in charge of activities carries out their activities within the specified time, because most of these activities adjust to the activities of boarding school and adjusted to the academic calendar.

Of course they will be more leverage in the implementation of work programs that have been well planned in advance. Then each person in charge carries out the programs together with other boards, the implementation of activities at Al-Muslimun Boarding School Sumberagung Plaosan Magetan is the development of predetermined plans to achieve a mutually agreed objective.

\section{d. Procurement of Labor}

15 Interview with caretaker, on June 23, 2017, 08.00-08.45 in his house 
1) Recruitment

Recruitment for educators, in this case the foundation or caretaker of AlMuslimun Boarding School Sumberagung Plaosan Magetan seek, collect, and attract the applicants to be empowered at Al-Muslimun Boarding School Sumberagung Plaosan Magetan. This recruitment stage lasts from the moment of seeking applicants to the application by applicants. Finally in the end performed the selection process in accordance with the required competency standards.

The steps that have been planned in Al-Muslimun Boarding School Sumberagung Plaosan Magetan, in the implementation of recruitment among them identifying vacant positions by attention to the management of human resource planning that has been prepared.

2) Selection

Through the selection carried out in the selection of educators at the AlMuslimun boarding school Sumberagung Plaosan Magetan, it will select candidates who meet the requirements as determined by the boarding school.

This selection process involves a series of stages and takes time before personnel decisions are taken. It is also to determine whether the applicant is accepted or not. The next step is to complete the application file that has been made then the school held a test. One of them is micro teaching in class or face to face with learners. With this practice of learning, it will be found the potential or ability of teachers in teaching. There is also an interview test of the applicants to look for who is the most qualified. From several candidates who have been elected then they are required to meet administrative requirements. For those who already met the requirements then they will be given special guidance on everything related to the field that they have chosen previously. ${ }^{17}$

3) Orientation

The orientation process given to new teachers is usually accompanied by one of the teachers at Al-Muslimun Boarding School of Sumberagung Plaosan Magetan. Among its functions is to introduce about the culture of boarding school, introducing the administrators and assemblies of teachers, and introduce the order of students both man and woman. All delivered gradually during the orientation period.

With the orientation the new employees will know or more familiar with what is in Al-Muslimun Boarding School Sumberagung Plaosan Magetan. ${ }^{18}$

17 Interview with vice headmaster of curriculum, on July 8, 2017, 08.00-08.45 in teachers' room 


\section{e. Development and Training}

There are two kinds of development and training that are done they are from outside of the institution and from within the institution. Among the forms from outside of the institution is the sending of several teachers to attend various events and activities such as seminars, scientific forums, training, and workshops organized by a particular institution.

f. Compensation

The compensation provided herein is in the form of money granted in accordance with the date. There are also additional incentives for outstanding teachers and employees. ${ }^{19}$

Other forms of compensation provided by foundations to teachers and employees who meet specific criteria are family allowances, home facilities for families, and some household needs such as rice, sugar, bath soap and laundry soap.

With this additional compensation and incentives, it can provide work comfort, encourage morale and dedication of personnel, as well as become a motivation for all teachers and employees to further improve his work in boarding school.

\section{g. Dismissal}

In general these dismissals are caused by employee desires such as termination of employment contracts, pensions, or other reasons. Also happen on the policy of the organization for certain reasons.

However, the dismissal occurring at Al-Muslimun Boarding School Sumberagung Plaosan Magetan is usually for teachers who are out of contract, while the teacher wants to gain experience elsewhere or wish to continue their education so they do not extend the contract in boarding school.

Usually the pension is on their request after the contract expired by filing a petition, and then the request is approved by the al-Muslimun foundation. ${ }^{20}$

h. Evaluation

18 Interview with vice headmaster of curriculum, on July 9, 2017, 10.00-10.30 in the office

19 Interview with foundation's treasury, on July 5, 2017, 09.15-10.00 in the office 
Evaluation of the work program at Al-Muslimun Boarding School Sumberagung Plaosan Magetan is intended to assess all activities, then find the indicator that causes the success or failure of a goal achievement, so it can be used as the next study material.

Evaluation of the work program at Al-Muslimun Boarding School Sumberagung Plaosan Magetan is done periodically, i.e. once a month at monthly meetings.

By conducting an evaluation, it can be seen the effectiveness of every activity that took place in the boarding school, and able to know the weaknesses and advantages. Existing weaknesses can be overcome and their advantages can be maintained. In addition, it can be seen whether a series of all activities within the organization has been appropriate to achieve the expected goals.

\section{Human Resource Development Aspects}

a. Academic Guidance

Academic coaching is preferred for teachers and employees who have the potential and talent and meet the specific requirements set by the foundation. In this case they are directed to pursue higher education in order to improve personal qualities.

Even some of those who enter this program, there is a must take leave in advance in order to concentrate for academic coaching. Thus they can be more leverage in taking advantage of chance and opportunities.

After the higher education, they continue their service at Al-Muslimun Boarding School Sumberagung Plaosan Magetan. Certainly, it is expected to share experiences with teachers and other employees. ${ }^{21}$

b. Professional Empowerment

Empowerment of professions that have been running in Al-Muslimun Islamic Boarding School Sumberagung Plaosan Magetan includes sending teachers or employees to attend the appropriate training. Then the teacher or employee who has completed the training is asked to spread his knowledge to others. ${ }^{22}$

c. Career Planning

Career planning for teachers and employees within the Al-Muslimun boarding school Sumberagung Plaosan Magetan, caregivers and foundations have helped,

21 Interview with caretaker on June 23, 2017, 16.00-16.40 in his house

22Interview with foundation on June 23, 2017, 12.30-13.00 in the office 
encouraged, and facilitated teachers and employees to improve their careers. Among them attribute the achievement of teachers and employees with improvements in both structural and functional positions. So in this case the party's managers are actively participating in promoting higher-performing teachers and employees to the next level. ${ }^{23}$

d. Welfare Improvement

The welfare of education personnel (HRD) conducted at Al-Muslimun boarding school Sumberagung Plaosan Magetan in the form of salary and honorarium in accordance with the schedule and on time. It is accompanied by incremental incentives for those who achieve and meet targets in their duties.

Besides, that also filled with some basic needs such as rice, sugar, and soap for the already married. Even for dishes and vegetables have been prepared and can be taken directly to the kitchen of boarding school and then taken to each home.

Neither the non-material nature such as satisfaction and comfort work also get special attention from the caregivers and foundations, for example; placing teachers and employees in accordance with their abilities and interest, conducting deliberations in the determination of their position and duties, so that teachers and employees can accept the assigned task and receive it with pleasure. ${ }^{24}$

\section{Conclusions}

Based on the results of research that has been described then it can be concluded that: [1] Managerial and operational, the function of human resource management has been applied in Al-Muslimun Boarding School Sumberagung Plaosan Magetan quite well. This can be seen in the process, implementation, and procedures in the phases of planning, management, labor procurement, compensation, development and training, gradual evaluation and dismissal of work although there are some minor evaluations that should be considered and refined in the future. Forms of programs that have been realized include; (a) sending the teachers to various trainings and seminars, (b) directing and encouraging human resources with interests and achievements to increase their academic by endure higher education; (c) guide teachers and employees and nurture them to improve the quality of work, (d) build a healthy competitive culture among teachers and employees, (e) placement of positions tailored to the ability,

23Interview with foundation on June 24, 2017, 08.30-09.00 in the office 
achievement and interests, and (f) provide material and non-material compensation equitably, and even provide additional incentives for those who meet the criteria. All in a frame of four aspects of development; (a) academic coaching, (b) professional empowerment, (c) career planning, and (d) improvement of welfare. [2] The management of human resource development applied in Al-Muslimun Boarding School Sumberagung Plaosan Magetan has proven very positive role to the quality of performance and improvement of education quality. [3] Some of the supporting factors already possessed in the successful implementation of human resource development management within the Al-Muslimun Boarding School are all properly maintained and upgraded. As for some inhibiting factors that still exist, should be prepared steps so that the completion of the future will no longer be a barrier to success in improving the quality of education in the environment of Al-Muslimun Boarding School through the management of human resources development. 


\section{BIBLIOGRAPHY}

Abu Sinin, Ahmad Ibrahim, Manajemen Syariah; Sebuah Kajian Historis dan Kontemporer (Al-Idārah fì al-Islām), terj. Dimyauddin Djuwaeni, Jakarta: PT Raja Grafindo Persada, 2006.

Adiningsih N., "Kualitas dan Profesionalisme Guru”, Pikiran Rakyat, 15 Oktober 2002.

Anwar, H. Moch. Idochi, Administrasi Pendidikan dan Manajemen Biaya Pendidikan, Bandung: Alfabeta, 2004.

Arifin, I, "Profesionalisme Guru: Analisis Wacana Reformasi Pendidikan dalamEra

Globalisasi”, Makalah dalam Simposium Nasional Pendidikan di Universitas Muhammadiyah Malang, 2000.

Arikunto, Suharsimi, Prosedur Penelitian Suatu Pendeketan Praktek, Edisi Revisi V, Jakarta: Rineka Cipta, 2002.

Cowan, J. Milton, Hans Wehr; ADictionary Of Modern Written Arabic, London: Otto Harrassowitz, 1971.

Danim, Sudarwan, Visi Baru Manajemen Sekolah, Jakarta: Bumi Aksara, 2007.

Davis, K. \& Newstrom, J.W, Perilaku dalam Organisasi, Edisi ketujuh, Jakarta:

Penerbit Erlangga, 1996.

Depdiknas, Kamus Besar Bahasa Indonesia, Jakarta: Balai Pustaka, 2001.

Drost, Sekolah: Mengajar atau Mendidik?, Yogyakarta: Kanisius, 1998.

Elias, Elias A. dan E. Elias, Elias, Modern Dictionary, English-Arabic, Beirut: Dar al Jael 1988.

Fatah, N, Landasan Manajemen Pendidikan, Bandung: Remaja Rosdakarya, 1999.

Fattah, Nanang, Landasan Manajemen Pendidikan, Bandung: PT Remaja Rosdakrya, cet ketujuh, 2004.

Gomes, Faustino Cardoso, Manajemen Sumber Daya Manusia, Yogyakarta: ANDI Ofset. Forsdale, 1981.

Good, V. Carter, Dictionary of Education, New York: McGraw-Hill Book Company, 1959.

Hafidhuddin, Didin and Hendri Tanjung, Syariah Principles on Management in Practice, Jakarta: Gema Insani, 2006.

Hamalik, Oemar, Evaluasi kurikulum, Bandung: Remaja Rosda Karya, 1990. Hook, John R., Memotivasi Karyawan, Yogyakarta: Tugu, 2006.

Indrawijaya, Adam I., Perilaku Organisasi, Bandung: Sinar Baru Algesindo, 2002.

Marmo dan Triyo Supriyatno, Manajemen dan Kepemimpinan Pendidikan Islam, Bandung: Refika Aditama, 2008. 
Miles, Manthew B dan A. Michael Huberman, Terjemahan Tjejep Rohendi, Analisis Data Kualitatif, Jakarta: UI Press, 1994.

Moleong, Lexy J, Metodologi Penelitian Kualitatif; Edisi Revisi, Bandung: PT Remaja Rosdakarya, 2004.

Mulyasa, E., Manajemen Berbasis Sekolah; Konsep, Strategi dan Implementasi, Bandung: PT. Remaja Rosdakrya, cet. VII, 2004.

Nainggolan H., Pembinaan Pegawai Negeri Sipil, Jakarta: PT. Rineka Cipta, 1990.

Nata, Abuddin, Manajemen Pendidikan: Mengatasi Kelemahan Pendidikan Islamdi

Indonesia, Jakarta: Kencana Prenada Media Group, 2007.

Peraturan Pemerintah Nomor 19 Tahun 2005 tentang Standar Nasional Pendidikan,

Jakarta: Sesjend. Depdiknas, Balitbang.

Pidarta, I Made, Landasan Kependidikan Stimulus Ilmu Pendidikan Bercorak Indonesia, Jakarta: PT. Bina Rineka Cipta.1997. , Manajemen Pendidikan Indonesia, Jakarta: PT. Rineka Cipta, 2004.

Rivai, Veithzal, Manajemen Sumber Daya Manusia untuk Perusahaan; Dari Teori ke

Praktik, Jakarta: PT. Raja Grafindo Persada, 2005.

Rochaety, Eti, dkk. Sistem Informamsi Manajemen Pendidikan, Jakarta: bumi Aksara, 2005.

Sugiyono, Metode Penelitian Pendidikan Kuantitatif, Kualitatif dan $R \& D$, Bandung:

Alfabeta, 2006.

Sulistyorini, Hubungan antara Keterampilan Manajerial Kepala Sekolah dan Iklim

Organisasi dengan Kinerja Guru, Ilmu Pendidikan, 2001.

Supriyadi, Dedi, Mengangkat Citra dan Martabat Guru, Yogyakarta: Adicita Karya

Nusa, 1999.

Suryosubroto, B., Manajemen Pendidikan di Sekolah, Jakarta: PT. Rineka Cipta, 2004.

Tempe, A. Dale., Kinerja, Jakarta: PT. Gramedia Asri Media, 1992.

Undang-undang Nomor 20 Tahun 2003 tentang Sistem Pendidikan Nasional, Balitbang,

Depdiknas.

Undang-Undang RI Nomor 14 Tahun 2005. Tentang Guru dan Dosen, Bandung:

Penerbit Fokus Media.

Usman, Moh. Uzer, Menjadi Guru Yang Profesional, Edisi kedua, Bandung: Remaja

Rosdakarya, 2002. 